\title{
A KANGAROO RAT COLONY IN ALBERTA
}

\section{by Hugh C. Smith and Michael J. Hampson}

Provincial Museum and Archives of Alberta, Edmonton

The Kangaroo Rat (Dipodomys ordii) collected by the U.S. Biological Survey at Medicine Hat in 1931 was the first recorded occurrence of this mammal in Alberta (Anderson, 1946: 131). This specimen was also the first recorded in Canada, although several records now exist for Saskatchewan. In 1958 Soper $(1964: 178)$ made an unsuccessful survey of the EmpressHilda area in an endeavour to locate Kangaroo Rats after Nero (1956: 110) had reported them in 1956 to be within eight miles of the AlbertaSaskatchewan border at Mendham, Saskatchewan.

On June 23, 1969, while on a field trip sponsored by the Provincial Museum and Archives of Alberta, we came upon a colony of Kangaroo Rats approximately 30 miles southwest of Empress. Using the method described by Nero (1958:176) to capture Pocket Mice, we were able to collect seven specimens. These are now in the collection of the Provincial Museum. As well as the seven collected, 13 others were seen the same night. During the night of June 24-25 seven were sighted.

This colony was found along a weed-lined country road that ran through slightly rolling prairie. The vegetation cover of the surrounding land is principally grasses; however, some shrubs-sagebrush, wolf willow, and rose-are scattered over the area. Although most of this land is used for grazing livestock some has been brought under cultivation. No rats were found near the cultivated land; all the ones that we saw were on the road through the grassland.

Nero $(1956: 109)$ found the dens of the Kangaroo Rat in blow-out areas of sand dunes, and in association with the plant Psoralea lanceolata. In the colony that we found, there did not appear to be any preferences for plant associations, burrows being sur- rounded with sage, dandelion, blue bur, flixweed and grass. As there were no sand dunes in this area they apparently took the nearest substitute - the road grade and ditches. The sides of the road grade and to a lesser extent, the crown of the road, were used extensively for the burrows; the bottoms of the ditches and the outside banks of the ditches were used to a lesser extent. The surrounding grassland did not appear to be occupied.

There were no mounds associated with this colony. The holes were dug into the roadway and all excavated earth was removed from the vicinity of the hole. The opening of the holes was approximately four and one-half inches in diameter, and the holes were quite conspicuous.

Judging by the number of burrows the colony extended for approximately three miles along the road and was road-width wide.

The extent to which the Kangaroo Rat has become established in Alberta is not known at present. Soper (loc. cit.) believes that they may occur in likely habitat anywhere in southeastern Alberta, south of the Red Deer River. Now that they have been confirmed as an established member of the fauna of Alberta, reports of other findings will no doubt come to light.

In this connection two incidents should be mentioned. The first occurred shortly after we had found the above-mentioned colony. We were in conversation with two farmers in the Hilda area, and we asked them if they had ever seen any Kangaroo Rats. One of them replied that he had not, but that a friend of his had picked up an animal that he thought was a Kangaroo Rat. When asked as to when and where this had happened he said that is was "a couple of years ago now, and it was near the River." 
The second report was from the Warner area. While we were stopped at the home of friends in Warner, our conversation eventually turned to the discovery of the Kangaroo Rat colony and to a discussion of how rare these animals were in Alberta. To our surprise the lady of the house stated that while she was working in the county office, a farmer had brought a strange looking animal into the office for identification. Apparently no one in the county office was able to identify it so they referred to some books for help. After a perusal of several books the only conclusion they could reach as to the identification of this animal was that it was a Kangaroo Rat. When we asked her where this animal had been picked up she was not sure but thought it was east of the town of Milk River.

With the publication of this note more reports may be forthcoming. If anyone knows of such a colony or of any sightings of Kangaroo Rats, the senior auchor would appreciate hearing from these people so that a more definite distribution pattern may be worked out for Alberta.

\section{LITERATURE CITED}

Anderson, R. M. 1946. Catalogue of Canadian mammals. Nat. Mus. Can., Bull. No. 102. Biol. Series 31. p. 131.

Nero, R. W., and R. W. Fyfe. 1956. Kangaroo rat colonies found. Blue Jay, 14:107-110.

Nero, R. W. 1958. Additional Pocket Mouse records. Blue Jay, 16: 176-179.

Soper, J. D. 1964. The mammals of Alberta. The Queen's Printer, Edmonton.

\section{COMMENTS ON THE RANGE OF THE NORTHERN POCKET GOPHER IN ALBERTA}

\section{by Michael Wilson, 196 Westover Drive, Calgary 5, Alberta}

J. Dewey Soper (1964. The mammals of Alberta. Hamly Press, Edmonton) defined the range of one race of the Northern Pocket Gopher, Thomomys talpoides talpoides (Richardson), in Alberta as follows: "Sporadically throughout the aspen grove belt west to a line running from about Westlock southward through Stony Plain, Pigeon Lake, Rocky Mountain House, Sundre, Morley, Elbow Falls, Maycroft and Twin Butte to Belly River, Waterton Park; east to about Nanton and Blackie..." For three years I have made casual investigations of the distribution of this rodent in order to supplement Soper's data. Pocket Gophers or their burrows have been found at a number of localities which add to our knowledge of its distribution.

A heavy infestation, as evident from numerous fresh burrows, was observed from Cochrane west past the Jumpingpound SuIphur Plant, and at least to a point on Highway 1a one mile west of the Ghost River crossing. This agrees with Soper's data, which indicated Morley to be the western boundary of the range at this point.

Burrows were noted as fairly common in the immediate area of the University of Calgary Environmental Sciences Station at Barrier Lake, Kananaskis Valley. Zoology students at the centre in 1966 observed one live specimen. An incomplete skull (University of Calgary, Archaeology Colls., No. OS-329) was found by me two and one-half feet down in a cutbank of the Kananaskis River just north of its confluence with Ribbon Creek, and some distance south of the University Centre. It appears that the species exists in open areas west of the Moose Mountain dome, and adjacent to the Rocky Mountain Front Ranges.

Wayne W. Smith (pers. comm., 1968) reported that Pocket Gopher burrows were present quite far up the Sheep River valley, suggesting that this valley may provide an opportunity for the animals to extend their range somewhat to the west.

Burrows were observed along Willow Creek valley at least as far west 